\title{
Carpooling and the Pan-European emergency call 'eCall 112': connected cars and their potential for environmental and transport policy
}

\author{
Marco Domenico Schaefer \\ German Environment Agency, \\ Section I 2.1 Environment and Transport, \\ WoerlitzerPlatz 1, 06844 Dessau-Rosslau, Germany \\ Email: marco.schaefer@uba.de \\ Email: marco.schaefer@tu-berlin.de
}

\begin{abstract}
To meet transport sector obligations to emissions reductions, large effects may be derived from intelligent transportation systems (ITS) solutions. Substantial decrease of vehicle miles travelled (VMT) can be achieved using transportation systems management (TSM) measures, especially through high-occupancy vehicles (HOV) incentives. Of these, carpooling and vanpooling approaches proved to be effective. However, there is a lack of reliable enforcement procedures. A review of automated vehicle occupancy verification (AVOV) research and development (R\&D) is followed by a proposal focused on the Pan European emergency call 'eCall 112'. The concept explores options for an eCall 112 application as an enforcement tool in TSM operations with vehicle occupancy data contained in the minimum set of data (MSD) as the base for new road transport policy tools. A set of incentives is described which support transport and environmental objectives. The proposed enforcement may impact congestion levels in combination with HOV-lanes and without them. Climate, environment, and the performance of road transportation systems could benefit from integrated road safety and TSM operations.
\end{abstract}

Keywords: automated vehicle occupancy verification; AVOV; carpool; environment; general data privacy regulation; GDPR; information and communications technology; ICT; intelligent transportation system; ITS; transportation demand management; TDM; transportation systems management; TSM; transport policy; vanpool.

Reference to this paper should be made as follows: Schaefer, M.D. (2019) 'Carpooling and the Pan-European emergency call 'eCall 112': connected cars and their potential for environmental and transport policy', Int. J. Automotive Technology and Management, Vol. 19, Nos. 3/4, pp.341-369.

Biographical notes: Marco Domenico Schaefer is a Scientific Advisor for Environment and Transport at the German Environment Agency (Umweltbundesamt) located in Dessau-Rosslau, Germany. His professional experience is based on various roles in research, transport policy and transportation planning. His professional interests are focused on public transport, parking management and ridesharing (i.e., carpooling and vanpooling) 
This paper is a revised and expanded version of a paper entitled 'Smart European air quality \& climate policy measures based on vehicle occupancy and ITS' presented at the 5th Smart Urban Policy Futures Workshop, University of Greenwich, London, UK, 9-10 July 2018.

\section{Introduction}

To limit transport sector-related greenhouse gas (GHG) emissions in order to meet the objectives of the Paris Climate Agreement (UNFCCC, 2015; Bergk et al., 2017) and to implement local, national and European air quality standards, near-term changes in urban, regional, and long-distance road transport are imperative. At present, several EU member states including Germany are significantly lagging behind their air quality policy agenda and now strive for an appropriate set of measures with short-term efficacy and high cost-efficiency. Of all measures discussed in public and expert debates, driving bans, i.e., bans for almost all diesel engine vehicles-raise strongest opposition. Instead of implementing (diesel) driving bans, however, recent intelligent transportation systems (ITS) solutions, in particular the Pan-European emergency call (eCall 112) (Carroll et al., 2015; Stevens and Hopkin (2010), might best satisfy the necessary criteria to support timely and large-scale progress towards more sustainable road transport. This article explores these opportunities and concludes with recommendations.

\section{Background}

\subsection{Global aspects}

With the adoption of the Paris Climate Agreement the urgency (Noland, 2013; IPCC, 2015) for action has become clear. It is time to turn from debates about targets (e.g., $2^{\circ} \mathrm{C}$ or $1.5^{\circ} \mathrm{C}$ ?) to instruments (Knopf et al., 2017) and incentives.

The effectiveness of transport sector instruments to further improve ambient air quality via threshold legislation ${ }^{1}$ is expected (Reuter, 2013) to decline unless transport volumes - number of vehicles, vehicle trips, or vehicle distance travelled [vehicle kilometres travelled (VKT) and vehicle miles travelled VMT)] - are reduced significantly. Although essential differences in the environmental impacts of diesel fuelled vehicles compared to petrol cars might deserve deeper (Cames and Helmers, 2013; Walton et al., 2015; Thomopoulos and Harrison, 2016; UBA and BMU, 2017; Klebaner, 2018; https://www.transportenvironment.org/publications/ citybans-are-spreading-europe; http://urbanaccessregulations.eu/; http://gis.uba.de/ website/umweltzonen/umweltzonen.php) discussion, the focus here is on the development of a near- to mid-term solution addressing both environmental and transport related problems caused in large parts by single occupant vehicles (SOVs) and congestion.

In the following, a few spotlights on Germany (Section 2.2) and the UK (Section 2.3) are given, North American experiences with transportation systems management (TSM) are outlined (Section 2.4) before exploring the potential for innovation (Section 2.5) based on GALILEO and 'eCall 112'. In Section 2.6 carpooling, vanpooling and their 
impact on TSM are described, followed (Section 2.7) by the feasibility of automated vehicle $^{2}$ occupancy verification (AVOV). Data privacy and IT security issues are discussed in Section 2.8 and adaptive network signal control (ANSC) in Section 2.9. The author's concept is detailed in Section 3; findings and recommendations are given in Section 4.

\subsection{Germany}

Driving restrictions for (diesel) vehicles are regarded as inevitable according to a decision of the German Federal Administrative ${ }^{3}$ Court of February 27, 2018, which declared driving restrictions for diesel vehicles 'older' than Euro 6 and petrol vehicles 'older' than Euro 3 are actually and legally possible, if there is no appropriate alternative measure to timely meet European annual and hourly $\mathrm{NO}_{2}$ emission limit values. Further, for the focus of this article, the City of Stuttgart recently initiated the promotion of carpooling as part of the city's set of instruments (Stuttgart, 2018) towards multimodal urban transport and improved local and regional air quality.

\subsection{The UK}

In 2018, the UK Government required a number of cities - including the City of Nottingham - to establish 'clean air zones (CAZ)'. Nottingham had implemented a 'workplace parking levy (WPL)' (Hallam, 2015) in 2011, and since then strategies to constrain peak hour congestion (Dale et al., 2017), by adding new tramways and extending electric bus supply with the new funds generated by the WPL - around GBP 9 million annually - have raised public transport's mode share to 'above $40 \%$ of journeys in the city' (Joseph, 2016). The strategy of integrating the demand side and combining push-and-pull measures resulted in significantly improved air quality, and it has allowed the City of Nottingham to avoid ${ }^{4}$ the implementation of a CAZ. While some other cities and jurisdictions are considering a WPL, the majority of the UK cities and counties are struggling to cope with $\mathrm{NO}_{2}$ and particulate matter (PM) air quality threshold values.

\subsection{The USA and Canada}

Analysis of North American experiences of the past 4-5 decades reveal significant impact (Bradley et al., 1980) of carpooling and vanpooling: fewer vehicle trips and less VMT led to sinking volumes of emissions and contributed to reduced energy (Pratsch, 1975b) consumption. The strategy of building a network (Maclennan, 1995; Shewmake, 2012) of extra lanes for high-occupancy vehicles (HOVs) created shorter travel times for travellers sharing their rides.

This part of TSM, mainly in the USA ${ }^{5}$, led to criticism (Schiller, 1998; Poole, 2011a; Shewmake, 2012) of the HOV-lane concept as being too expensive, not environmentally sound, and inefficient. This criticism was met by advancing (Decorla-Souza, 2008; Decorla-Souza et al., 2011; Decorla-Souza and Kane, 1992; Poole, 2005, 2011a; Poole and Balaker; 2005; Poole and Orski, 2003; Poole and Swenson, 2012; Turnbull, 2002) the concept towards high occupancy toll lanes (HOT-lanes), express lanes, and managed lanes. 
Figure 1 Bus- and HOV-lane on Interstate 5 northbound near Seattle, WA, USA (see online version for colours)

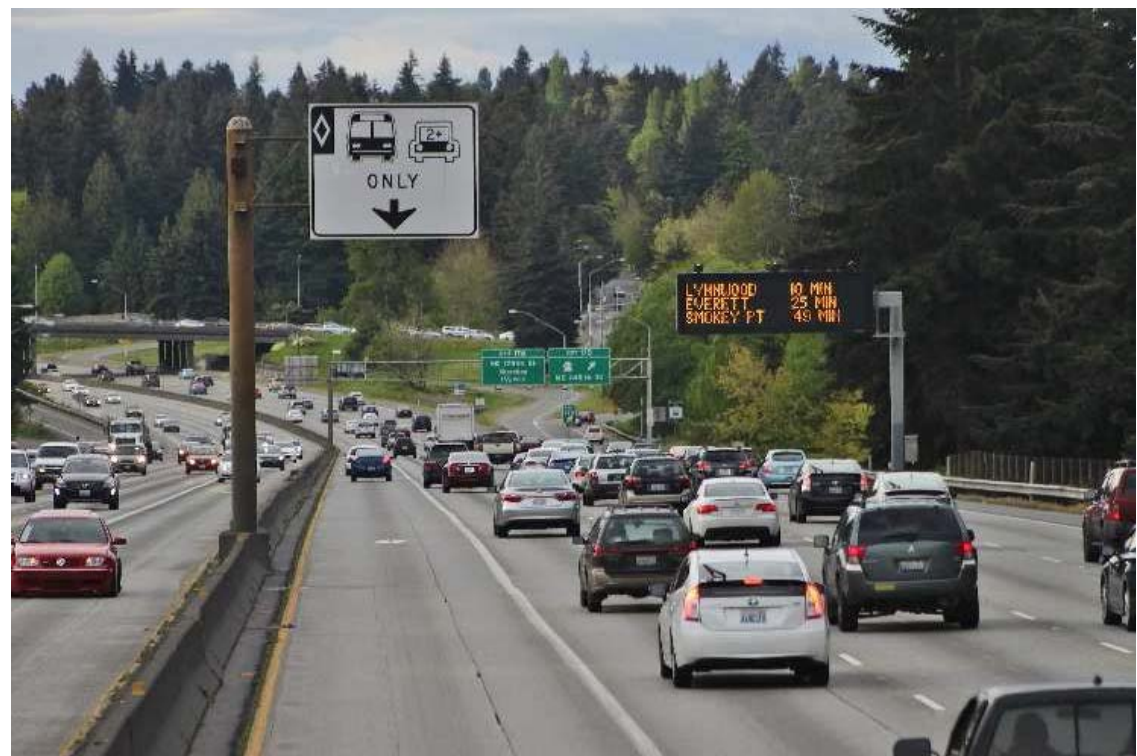

Source: Wikimedia (2017)

Figure 2 \#DummyInTheHOVLane (see online version for colours)

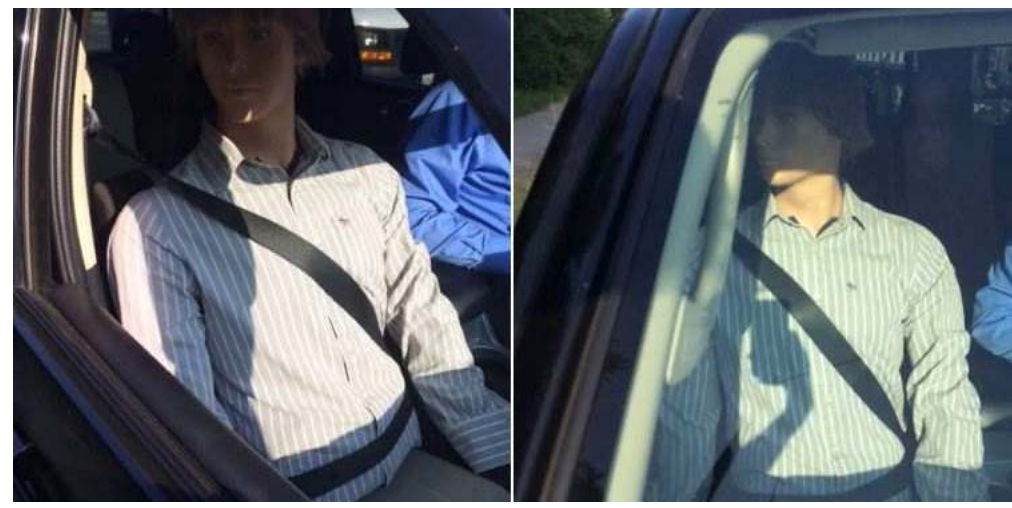

Source: FairFax County Police, Virginia, USA, @fairfaxpolice, 27 July 2016; https://twitter.com/hashtag/DummyInTheHOVLane?src=hash

Several recent (Goodin et al., 2013; Wood et al., 2017; Poole, 2017) studies on these new types of HOV-lanes indicate that the ideal solution is yet to be found. Ramp metering is yet another part of TSM applications; these are considered in Section 3. One big drawback of HOV concepts is based on unsatisfactory enforcement options.

On the one hand, low efficacy and poor efficiency characterise manual HOV-lane traffic controls: police officers positioned either in stationary roadside control points or in patrol vehicles on a highway certainly cannot meet the volume and quality requirements to check the actual occupancy of all vehicles by visual inspection. Besides, these manual modes of enforcement are expensive, and may also raise safety concerns. On the other 
hand, the US authorities at the Department of Transportation (US DOT) and the Federal Highway Administration (FHWA) have commissioned and performed a series of R\&D projects to find an appropriate technology for AVOV. ${ }^{6}$ Since the early 1990s (Billheimer, 1990; Turner, 1998; Schijns, 2004; Tyrer and Andrew, 2005; Ballantyne, 2006; Goodin et al., 2007; Ungemah et al., 2008; Poole, 2011b; Morris et al., 2017) substantial efforts have been made with the focus on roadside enforcement strategies. However, a 'breakthrough' is still missing. Due to these short-comings, HOV privileges lack full societal acceptance. Obviously, a fine structure ${ }^{7}$ of $\$ 125$ for a first offense up to $\$ 1,000$ for a fourth offense (i.e., a violation of HOV requirements) is not deterring; this underlines the need for improved traffic control options.

With growing efforts in ITS research and development (R\&D), various approaches to TSM have emerged now focused on in-vehicle systems.

\subsection{ITS in the European Union}

To improve safety in road transport, the European Union (EU) and their member states have pursued the goal of deploying an automated emergency technology ${ }^{8}$ since 2003 . Today, the European Automobile Manufacturers Association (ACEA) ${ }^{9}$ widely supports these efforts. The eCall system builds upon earlier long-term EU-projects such as GALILEO $^{10}$ and EGNOS ${ }^{11}$ which now contribute to the technology framework for the Pan-European eCall 112. The EU-wide deployment of the eCall infrastructure was accomplished in October 2017; the mandatory provision of eCall 112 technology devices in all new passenger vehicle types is effective from March 31, 2018. The eCall infrastructure deployment comprises both necessary roadside infrastructure and the GALILEO/EGNOS-based telecommunications infrastructure. The system roll-out will later be expanded to industry requirements for powered two-wheelers as well as for buses, coaches, and heavy goods vehicles (HGVs). ${ }^{12}$

As well as regulations and standards ${ }^{13}$ for vehicle type approval, for the approval of eCall devices and units, the technical and operational standards for roadside infrastructure and the involved standards for telecommunication devices and procedures, the minimum set of data (MSD) is a central element of the eCall 112 system as defined by the EU legislation.

After a crash event, the MSD is automatically transmitted to the nearest public safety access point (PSAP) via an in-band modem using circuit switched technology as SMS or other data connection and via voice connection. The system activates both microphone and speaker subsystems of the eCall in-vehicle device to enhance the probability of communicating with the driver or any passenger.

The resulting advantages are numerous:

1 The transmission of the vehicle type (passenger car, two-wheeler, bus or coach, or a $\mathrm{HGV}$ ) allows the PSAP staff to follow the correct check list and tick most important items first.

2 The location of the vehicle can be explored immediately and with high precision, including the direction of travel.

3 The passenger(s) might not be able to call via their mobile phones.

4 Even if they could, they might not know or not remember the correct call number. 
5 When travelling abroad, they might not be capable of either understanding or expressing themselves adequately - or both.

6 If the vehicle driver is not the owner, he might not be aware of all relevant details such as the propulsion type, which can be critical.

7 The re-dialling function of the eCall allows the staff involved to distinguish re-sent data messages from first-time messages, and to identify the precise time interval since the crash occurred.

8 Driver and passengers have the chance to press a button instead of using their phone.

9 Staff at the PSAP are enabled to send all required data to the nearest available and most appropriate unit (ambulance, fire brigade, police), and simultaneously pass the event data to the TSM operator in order to take action, including informing the public thus reducing the incidence of secondary accidents.

10 Shorter response times reduce congestion after any incident.

Figure 3 eCall system overview, EU project website 'harmonised eCall European deployment' (see online version for colours)

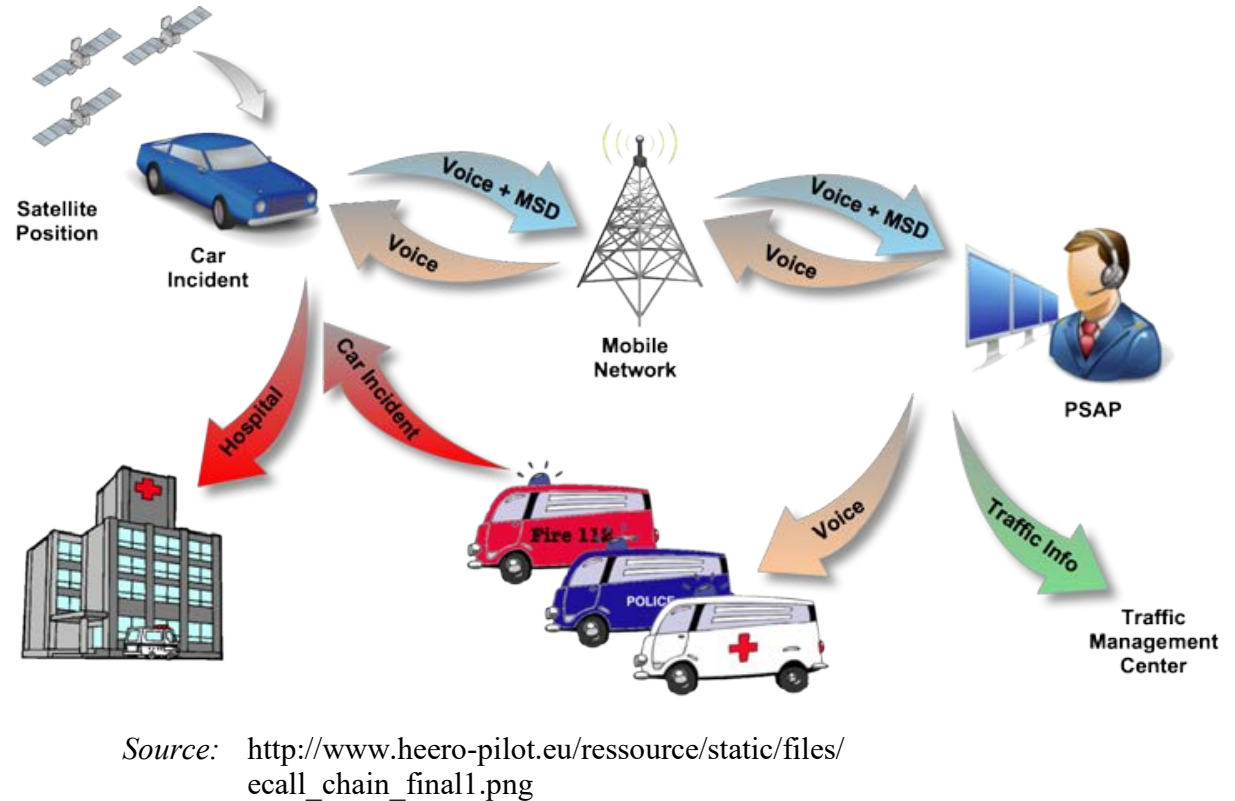

As described by Iparraguirre and Brazalez (2016), the MSD standardised in CEN TS 15722:2015 comprises the optional data field 'number of passengers'. Note that:

1 Here the number of passengers is derived from the number of fastened seatbelts.

2 The number of passengers includes the driver.

First eCall retrofit devices as shown in Figure 4 are designed for the standard 12 V DC plug available in every passenger car today and advertised ${ }^{14}$ since January 2018. Connected with the user's smartphone via Bluetooth, these retrofit devices allow for the same functionality as the eCall device integrated in any new vehicle type. This near-term 
upgrade option for the existing vehicle fleet or comparable devices could bridge the gap until the vehicle fleet turnover will have led to wider market penetration. EU regulation (EU) 2015/758 allows that added-value services (EP and EU-Council, 2015) may build upon the eCall 112, but that the eCall itself is handled with priority ${ }^{15}$ at any time and under any circumstance. To make sure that all standards are met, there are highly detailed legal and supplemental documents on the procedures for the approval (Carroll et al., 2015) of vehicle types, components, and separate technical unit approvals.

\subsubsection{Can this progress matter for climate protection?}

With these innovations already available at technology readiness level (TRL) scale (Towery et al., 2017) level 9 technology refined and adopted, and a wide-spread market penetration expected shortly, new transport policy measures integrating these information and communications technology (ICT) innovations can be developed. If implemented this progress may considerably contribute to GHG emission reductions.

Figure 4 TEP 120 retrofit eCall for the 12 V DC outlet based on crash detection technology (see online version for colours)

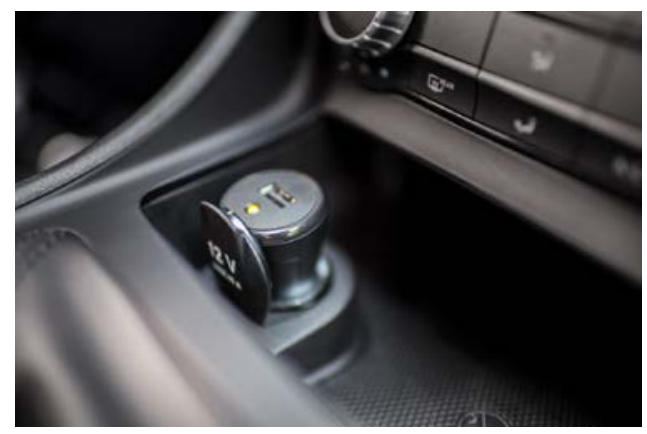

Source: https://www.bosch-presse.de/pressportal/de/en/emergency-callsystem-for-retrofitting-152768.html

\subsection{The impact of carpooling and vanpooling on transportation systems management}

\subsubsection{General considerations}

Fostering higher vehicle occupancy has been an essential for transport policy and environmental policy in the US for decades. Traditionally, this has been implemented in series of R\&D projects and programs for carpooling and vanpooling focused on commuter transportation.

Since 2013, 'ridesharing' has an ambiguous ${ }^{16}$ meaning: It may either describe emerging commercial services also dubbed 'social taxi', 'ridesourcing', 'ridehailing', and 'transportation network companies (TNCs)' as Uber, Lyft, etc. These new taxi-like modes of transport mean additional vehicle trips made for passengers which in largest (Shaheen et al., 2017; https://www.accessmagazine.org/wpcontent/uploads/sites/7/2017/ 06/Shaheen1.jpg) part originally would have chosen public transport or a taxi, as Shaheen et al. (2017) have shown in a Californian case-study. Schaller reports a steep increase (Schaller, 2017, 2018) in VMT caused by TNC vehicle trips significantly contributing to 
traffic volumes in New York City. These additional trips do not mitigate congestion, etc. and therefore TNCs are not included here.

Before these new modes of transport emerged, ridesharing was a synonym for carpooling and vanpooling, describing shared rides filling empty seats in privately held vehicles (carpooling) in trips that are made anyway. Vanpooling - in the 1970s also buspooling (Pratsch, 1975a) was reported - eliminates even higher numbers of vehicle trips, as these vans may contain up to 15 seats. 1970s US reports (Sears, 1979) grouped the numerous vanpooling projects into three approaches: employer sponsored; third-party sponsored; and driver owned and operated. 'Third-party' here refers to a variety of financing and organising options, among them not-for-profit organisations, leasing agencies, ridesharing agencies, and more recently transit (Murray et al., 2012; Chan and Shaheen, 2011) operators.

In the following, firstly a definition of congestion is given, then selected examples of carpooling potential and finally carpooling short-comings are discussed.

Congestion mitigation is among the major carpooling effects. There are diverse (Minett, 2014) definitions of congestion; the relevant type here may be characterised as roads full of (almost) empty cars. Komanoff (2001) depicts this congestion type in his analysis of traffic in New York City in the aftermath of 9/11 published shortly after the Manhattan carpool rule was enacted by Mayor Giuliani: "Single-occupant vehicles make up more than half of Manhattan-bound morning traffic but they transport fewer than a third of all highway commuters. In other words, a minority of solo drivers is taking up an absolute majority of road space. The resulting congestion ensnares everyone from car-poolers and bus riders to the solo drivers themselves. Vans carrying tradespeople and trucks laden with goods the city needs to keep its economy going have been especially hard hit. Think of all eight crossings into Manhattan as a 20-lane highway. Single-occupant vehicles, accounting for 53 percent of traffic, occupy 11 lanes but they deliver only 30 percent of commuters - just six lanes' worth. That's five lanes wasted by solo drivers - the equivalent, say, of closing both the Queens Midtown Tunnel and the Brooklyn Bridge. Radio traffic reports call it 'congestion', but it's really just inefficiency." The Carpool Rule (Kaufman et al., 2002) (solo driving ban, SOV ban) enacted by Mayor Giuliani and confirmed by Mayor Bloomberg led to a deep reduction in vehicle traffic volumes entering southern parts of Manhattan during peak hours, and to steep increases (Transportationalternatives, 2002; TSTC, 2002) in transit ridership. Mayor Bloomberg enacted another temporary SOV ban after Superstorm Sandy. In order to make more efficient use of road infrastructure - both on highways and in any urban context - the following describes applied solutions.

\subsubsection{Applied solutions}

Since 1974, the Environmental Protection Agency (U.S.EPA) has specified carpooling as an instrument (Pratsch, 1974; U.S.EPA, 1974, 2001, 2008, 2011) for reducing automobile traffic, especially in the context of federal air quality standards. One of the most impressive mode shifts towards carpooling, vanpooling and express bus services is described by Pratsch (1975b). The Tennessee Valley Authority (TVA) initiated a leasing-based vanpooling service and a transportation broker system. Within two years, drive alone mode shares were reduced from $65 \%$ to $23 \%$. 
Figure 5 Mode shift of TVA work force 1973-1975 (see online version for colours)
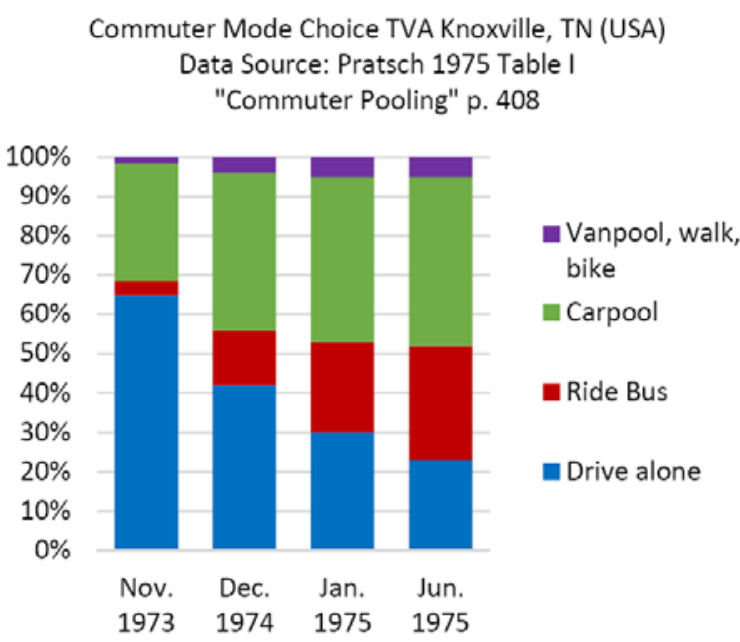

Source: Pratsch (1975b, p.408)

Case studies of carpooling programs funded under the Emergency Highway Energy Conservation Act of 1974 found that one highly successful programme in Portland, Oregon, attracted more than 22,000 carpoolers, and proved [Pratsch, (1975b), p.409] very cost-effective with a benefit-cost ratio of 56 to 1 , saving more than $\$ 12$ million and almost 6 million gallons of gasoline in the first year. The overall commuter ridesharing programme's potential [Pratsch, (1975b), p.403] to save oil was estimated at 500,000 barrels per day. In 1986, Pratsch explored the demand for peak hour VMT reductions to eliminate congestion, and with regard to the two HOV lanes on I-395 in Northern Virginia he reported a 10\% decline of vehicles entering Washington, DC, and a reduction of at least $20 \%$ of commuter vehicles inside the beltway.

In 1992, Indonesia's capital Jakarta enacted the three-in-one carpool rule for some of the major road connections to and within the city centre and lifted (Anderson, 2017) this regulation in 2016. A 2016 study on before/after changes in average travel times based on anonymised Android cell phone data provided by Google Maps revealed strong evidence for the congestion mitigation effects of the three-in-one carpool rule: on average, morning peak delays increased by more than $47 \%$, and evening peak delays by $89 \%$ after the regulation was lifted. Further, congestion spread over larger parts of the city which had previously not been affected by the carpool rule (Hanna et al., 2017).

By combining carpooling or vanpooling with parking policies, the total outcome may be even larger, as shown by Shoup (2005; http://shoup.bol.ucla.edu/ParkingCashOut.pdf), etc (Pratsch, 1986). Further investigations on carpooling - including casual carpooling and vanpooling also show (Pratsch, 1975b; Minett and Pearce, 2011; Nigro and Burbank, 2012; Minett, 2014) significant reductions in congestion levels, energy consumption, and transport-sector emissions.

\subsubsection{Studies and scenarios on carpooling potential}

In their 1982 publication on behalf of the German Academy for Spatial Research and Planning (ARL), Heinze et al. (1982) found that a 30\% increase in average commuter 
vehicle occupancy towards 1.47 would provide an additional capacity in the order of the total peak hour demand for public transport in former West-Germany. In an early 1990s, research project on behalf of Daimler Benz AG, Spiekermann and Wegener (1992) (cf. http://www.irpud.raumplanung.tu-dortmund.de/en/111/) explored the carpooling potential within travel-to-work trips for the City of Dortmund, Germany, and for one of the scenarios they found "More than two thirds of all work trips are poolable, and more than half of all car kilometres of work trips could be saved."

In 2000, Kutter investigated mode choice in the German Federal State of Saxony and calculated the carpooling potential. He found that in Dresden suburbs and Saxon rural areas the observed vehicle occupancy had risen (https://www.vda.de/de/services/ Publikationen/fat-schriftenreihe-154.html) to 1.21 for travel-to-work up to 1.39 for errand trips which outpaced public transport by far; Kutter concluded that these high carpooling mode shares constitute a form of 'private public transport' contradicting the strict regulations in Germany's legal framework.

In 2005, the International Energy Agency (IEA) classified the carpooling potential to save oil as very large. A high potential of carpooling for TSM and for climate protection and a mainly untapped resource as a business case were explored by Hartwig and Buchmann in 2007 (https://de.scribd.com/document/153707176/NRC-TR-2007-003).

In 2009, Clabburn and Lane estimated 38 million empty seats commuting on the UK roads every day and calculated that a rise in average vehicle occupancy to two would result in a decline of 9 million tonnes of $\mathrm{CO}_{2}$ emissions annually.

For 2009, the US DOT (2010) reported additional fuel consumption due to congestion of about 3 billion gallons of fuel per year for the USA in 2009; according to Schrank et al. (2012), these congestion levels accounted for " 56 billion pounds of additional carbon dioxide $\left(\mathrm{CO}_{2}\right)$ GHG released into the atmosphere during urban congested conditions" per year for the USA in 2011.

In his address to the inaugural meeting of the Ridesharing Institute in 2011, Minett compared capacity issues in road transport to former and recent ICT developments. $\mathrm{He}$ found that under actual road transport conditions, less than 3\% of the capacity is used, and concluded that we should mitigate congestion by broad banding our roads through fostering carpooling, vanpooling, and public transport.

In a scenario analysis for California, Rodier et al. (2016) explored the potential for GHG emission reductions of a regional dynamic ridesharing (= carpooling and vanpooling) system including various combinations of different levels of pricing VMT, different participation rates for the regional dynamic ridesharing systems, and with or without the ridesharing option. It turned out that pure pricing approaches without ridesharing were far less effective compared with their corresponding combination of pricing and ridesharing. As a result, for the maximum participation scenario, between $32 \%$ and $41 \%$ of all trips were found to be shareable. VMT reduction levels varied between $13 \%$ for the maximum VMT fee of $\$ 0.50$ without ridesharing and $28.5 \%$ for the same pricing scenario combined with ridesharing (Rodier et al., 2016).

\subsubsection{Carpooling and vanpooling research needs}

Carpooling and vanpooling approaches are still confronted with a number of limitations. The following is restricted to the remaining essential barriers: 
1 As shown above, HOV privileges lack acceptance due to poor enforcement, therefore the concept focuses on reliable new enforcement options. The large array of R\&D described in Section 2.7 has not yet delivered applicable solutions.

2 Lack of reliable vehicle occupancy data: unlike uncounted libraries of public transport ridership statistics, there is no accountable up-to-date resource for vehicle occupancy. As there'is no inevitable economic connection when sharing rides - it can be based on a private not-for-profit basis - sharing does not necessarily involve any payment transaction. Data on ride matching activities - e.g., number of offered car passenger seats, number of requested rides, number of matched and unmatched trips - are usually treated as commercially sensitive by private operators, thus data availability is low. By and large, published data on vehicle occupancy have to be seen as ballpark figures rather than results of counting or calculations.

3 The lack of a critical mass of users and the undesirable effects of proprietary systems (Chan and Shaheen, 2011; Schaefer, 2011) on market formation could be addressed by actions on local up to (supra-)national level to develop pilot projects, incentives, campaigns and funding programmes to foster carpooling; supplemental monitoring and enforcement may contribute to higher public acceptance.

4 Innovative economic incentives to raise carpooling participation have to be developed as well: recent publications (Minett, 2015a, 2015b, 2016) explore the potential of financial incentives like payments for drivers' mode shift towards being a passenger in a carpool.

\subsection{Automated vehicle occupancy verification}

AVOV refers to automated detection and verification of vehicle occupancy in conventional vehicles; autonomous or automated vehicles are not explored here. To the author's knowledge, only a few comparative studies are available. In the 1990s and early $2000 \mathrm{~s}$, a number of technologies had been investigated for their technology readiness, among them thermal imaging, heartbeat and breathing ${ }^{17}$ monitoring, and fingerprinting and biometric recognition as in a Volvo pilot study; several of these research paths have been conceded in the meantime. In the literature, approaches have been split into roadside-based systems versus in-vehicle systems; other distinctions include moving traffic vs. stationary traffic.

\subsubsection{Moving traffic}

1 photography and stereo imaging (Goodin et al., 2007)

2 structured lighting (LED) (Schijns, 2004; Morris et al., 2017)

3 video (Billheimer, 1990; Turner, 1998)

4 smartcard and/or transponder technologies (Schijns, 2004; Wood and Jones-Meyer, 2016)

5 infrared-laser-based detection and verification attempts (Artan et al., 2014, 2016; Ballantyne, 2006; Kalikova et al., 2015; Morris et al., 2017; Tyrer and Andrew, 
2005; Ungemah et al., 2008; Xu et al., 2014; for TruCount by NEC cf. https://www.necam.com/AdvancedRecognitionSystems/Products/TruCount)

6 RFID technology (Kelley, 2007)

7 inductive power transmission (Albesa and Gasulla, 2015)

8 weight sensors (Kisic et al., 2017)

9 ultrasonic sensors (Schijns, 2004)

10 neural networks for imaging analysis applications (Wshah, et al., 2016) and machine learning approaches (Xu et al., 2014)

11 Bluetooth occupancy detection (https://www.gocarma.com/) via in-vehicle systems.

\subsubsection{Stationary traffic}

ICT-based developments have led to new options (Zanella et al., 2014) in parking control and pricing. Especially sensor technologies allow for area wide automated control or low-cost and long-term availability ${ }^{18}$ of parking lot occupancy sensing. The internet-of-things (IoT) allows for an ample variety of new devices supporting smart mobility projects. Parking lot-based deployment of transponder technology combined with smart cards at university campuses in the US provided parking discounts for two or more carpoolers concurrently swiping their student ID cards (Mccoy et al., 2016).

\subsubsection{Review of previous attempts}

The state of technology development is usually categorised by 'technology readiness levels' ranging from basic principles and research (TRL 1) to technology refined and adopted (TRL 9) (Towery et al., 2017).

There are four essential reasons to classify the reviewed technology approaches as not yet applicable in real world use:

1 Either an experimental state of the applied detection method or device.

2 As is the case for many of the in-vehicle systems, it is due to the inability to communicate their results, i.e., vehicle occupancy data, out of the vehicle and into roadside TSM operations.

3 The most important drawback for the implementation of these detection and verification devices is related to their costs. With estimated prices of a single infrared (IR) camera for roadside vehicle occupancy inspection of one lane in the order ${ }^{19}$ of $\$ 150,000$, hardly any TSM authority could cope with the costs incurred for the setup for all lanes positioned at least at every access and egress point in a particular metropolitan area. DeCorla-Souza (2008, p.37) provides valuable data and insight to grasp the dimension of typical Metropolitan Planning Organisation (MPO) wide tolling systems.

4 Last but not least, several pilot applications proved as too slow: TSM operations require high throughput rates of vehicle occupancy detection data which manual inspection cannot cope with; so far no reported R\&D pilot has reached the required TRL. The experiences with convolutional neural networks ( $\mathrm{CNNs})$ and other 
machine learning approaches in video imagery detection and verification systems appear as promising, but most probably not quite ready for real world applications as the processing speed capabilities are unclear. The level of deployment cost is unknown as well.

Goodin et al. (2007) classified detection technologies according to their capability of:

- $\quad$ penetrating vehicle windows

- $\quad$ all weather and day-/night-time operations

- $\quad$ resolving vehicle cabin details

- fast capture of vehicles moving at freeway speeds.

Ultra-wideband radar could not meet requirement no. 1 and was not considered, etc.; in 2007, near-infrared was the only technology to fulfil all requirements (Goodin et al., 2007). More recent publications added further requirements such as the capability to resolve heads and limbs; and finally, to meet legal requirements, enhance resolution for the use of imagery detection for individual identification in roadside systems.

As Poole investigated in 2011, IT security and data privacy issues turn out as a high barrier to the reported AVOV attempts, comprising both roadside systems and in-vehicle systems. Poole pointed out that therefore and because a high market penetration of the US fleet ready for vehicle-infrastructure-integration (VII) could not (Poole, 2011b) be expected before mid-2030s, near-term solutions first of all require a policy change. According to Poole (2011b, Part 4), 'declaration transponders' and the restriction of eligible HOV lane use to pre-registered carpools should be applied. 'Integrated system' would indicate the combination of AVOV and the compliance (Chan et al., 2011) of road travellers.

Building on these results of Poole (2011b) and Chan et al. (2011), a first test of toll-discounts for pre-registered carpools in a pilot program to combine toll operations on a toll road and an expressway with Carma's dynamic ride matching services in Austin, Texas (USA) proved (Wood and Jones-Meyer, 2016) viable; however, the rate of participation was disappointing. The project evaluation identified the insufficiency of the supplied incentives as the key factor. The smartphone (Bluetooth)-based AVOV and the ride matching services by Carma are currently being explored in a pilot programme for Dallas and Fort Worth, Texas (USA). The Austin project relied on the TxTag transponder technology but did not involve the abovementioned Bluetooth occupancy detection which is now tested in the Dallas-Fort Worth pilot.

\subsection{Data privacy and IT (cyber) security}

Among the obstacles to more widespread use of digital devices and services are:

1 the lack of reliable data privacy solutions

2 a missing cyber security framework.

These have to be addressed comprehensively and most urgently, as the EU General Data Protection Regulation (GDPR) introduced ${ }^{20}$ strongly enforceable data privacy rights for citizens and customers as of May 2018. 
IT security and data privacy issues require adequate solutions and possibly include legal modifications. Without any change to the eCall 112 , there are already substantial concerns that individual rights to privacy protection could too easily be undermined by this progress. This comprises a technologically (Missiroli et al., 2014) and legally sound solution to the concerns as discussed in the context of mobility-related data and the need for certified anonymisation (Wojtowicz and Cebulla, 2017) techniques and procedures. Particular criticism associated with the eCall is focused on missing transparency and especially suspected lack of control: automated activation of any in-vehicle microphone(s) as part of the eCall in-vehicle device may easily enable electronic (Wisman, 2016) eavesdropping. In particular, dormant devices (Carroll et al., 2015) require a distinct legal definition. In the context of automated driving, threats and risks posed by potential attacks to take over control of any vehicle are growing, as described, e.g., by Morris et al. (2018).

\subsection{Adaptive network signal control}

Apart from approaches related to extra (HOV-) lanes and apart from the eCall technology, traffic control operations have been explored to reduce congestion (Bhuvaneswari et al., 2012; Li and Zhao, 2016) via demand responsive timing of traffic signals; Margreiter et al. (2014) point to the potential of ICT in traffic control measures to reduce energy consumption and transport emissions.

To reduce congestion levels and to minimise travel time for emergency ${ }^{21}$ vehicles and for public transport, area wide control systems for traffic lights as, e.g., in London, the $\mathrm{UK}^{22}$ can make use of on-board units (OBUs) and communicate via GPS and GPRS to receive and transmit real-time location data. These technologies do not rely on additional roadside infrastructure and allow for low-cost flexible application. Further research should consider ANSC technology to create travel time advantages for HOVs; however, without compromising road traffic safety, nor emergency vehicles' and public transport performance.

\section{Concept}

As shown above, 'threshold legislation' policies applied so far are insufficient to improve local air quality, to meet the Paris Climate Agreement, and to solve congestion problems substantially. A summary of Section 2 leads to the conclusion that a new approach must pursue a measurable reduction of overall VMT with a focus on peak hour demand. With regard to congestion, expected outcomes of the eCall 112 deployment might be limited: A benefit-cost study on the eCall-deployment in the UK resulted in negligible values of the congestion reduction effects caused by improved traffic management (Walker et al., 2010). However, additional effects due to higher vehicle occupancy as result of the proposed enforcement approach could improve the overall benefit-cost ratio substantially.

\subsection{Objective}

This overall objective can be achieved within individual motorised transport by incentives for HOVs and disadvantages for solo driving. Experiences in the USA and Canada have demonstrated the viability of fostering HOVs; however, these incentives 
lack applicable enforcement options. To the author's knowledge, there is neither an independently evaluated in-vehicle AVOV system nor any device ready for real-world application (TRL 9) capable of transmitting vehicle occupancy data out of the vehicle and into roadside TSM operations, nor an independently evaluated TRL 9 roadside AVOV system available as of today.

In the author's view, a promising concept could be created with the Pan-European emergency Call (eCall 112), third party services (TPS) and added-value services enabled by this process. It is based on EU-wide legislation (EU-Commission, 2013, 2017; EP and EU-Council, 2014, 2015; http://eur-lex.europa.eu/legalcontent/EN/TXT/?uri= OJ:L:2017:012:TOC) requiring the provision of eCall devices in every new vehicle type. The author's proposal would expand the eCall system to allow for integrated road safety and TSM operations leveraging highly reliable vehicle occupancy data provided by eCall 112. It would require minimal modifications to the legal framework.

Therefore, this proposal combines legal and technological components to create enforceable incentives for HOVs and a reasonable transport policy framework. With the implementation of the 'eCall 112', at least in the EU there is a realistic opportunity to employ ICT-based progress for TSM operations and to develop a reliable AVOV solution. Here, the participation of motorists using eCall 112 in TSM would be on a voluntary basis so that users (vehicle owners and drivers) can 'opt-in' to register for participation. A demonstration project could clarify if automated number plate recognition (ANPR), radio frequency identification (RFID) or transponder technology should be applied additionally for the distinction between vehicles of registered users versus non-users to adhere to data privacy regulations.

\subsection{Monitoring and enforcement}

\subsubsection{Implementation phases}

The concept is divided into two stages for implementation: in phase 1, EU legislation regarding the eCall 112 would be modified by:

1 Turning the transmission of the data field 'number of passengers' into a mandatory part of the MSD.

2 Allow multiple eCall 112-systems within any vehicle as soon as technology allows for it.

3 Integration of eCall 112 applications into EU regulations on TSM including road pricing and congestion pricing.

4 Essential improvements for higher data privacy and IT security.

In this first step of implementation, $12 \mathrm{~V} \mathrm{DC}$ plug retrofit devices (cf. Section 2.5) would be employed to detect and transmit current vehicle occupancy 'out of the vehicle' and feed it into TSM operations. Local, regional or national authorities for transport and/or the environment will be entitled to receive MSD data as any road transport safety and emergency authority like PSAP (see Section 2.5). This should be sufficient to run demonstration and R\&D projects on test sites, etc.

In phase 2, TPS based on eCall 112 may allow for advanced and integrated in-vehicle systems. Two additional automated detection (sub-)systems could be employed to 
supplement the eCall MSD data, e.g., weight sensors, and electric field sensors (Albesa and Gasulla, 2015; Kisic et al., 2017). Weight sensors are already part of airbag system installations built in many passenger vehicles. 'Cheating' an electric field sensor and a weight sensor and additionally cheating the eCall MSD number of passengers would be far more difficult and far less likely than simply fasten seatbelts on passenger seats filled with luggage, shopping bags, etc.

Further, mobile and roadside devices and software would be developed for integrated TSM and road transport safety operations. These attempts may use the vehicle identification number ${ }^{23}$ (VIN) which is already an integral mandatory part of the MSD in order to ease identification of any vehicle's emissions classification (EURO1-EURO6 d temp).

\subsubsection{Legal framework modifications}

Transport policy decision makers at involved levels of government and administration would create the regulatory framework to allow for HOV incentives and privileges, e.g., in road pricing, congestion pricing, parking pricing, and time savings, wherever appropriate.

Vehicle owners and drivers interested in making use of privileges for HOVs are given the choice to opt-in and register for using eCall 112 data in traffic controls. These registered users may take advantage of rebates on tolls or parking fees, free or discounted access to low-emission zones, preferential access to (highway) ramps, reserved parking, or priority signals at traffic lights whenever feasible. With no alternative TRL level 9 solution available, registration of interested vehicle keepers and drivers is necessary to adhere to data privacy principles.

This is a concept for a new type of environmental and transport policy that would focus on reducing vehicle miles (kilometres) travelled and reducing transport-sector emissions as far as possible. This concept would allow for an opt-in solution for users, i.e., no car driver and no car passenger would be forced to use any new device or service; rather, it should be designed to create an attractive alternative to driving alone, and, to create fair treatment of all travellers by allowing for correct and in-time on-site enforcement of HOV preferences. An ITS-based system would allow for pricing based on vehicle occupancy, congestion levels, and the emissions classification of the particular vehicle using the VIN transmitted via eCall 112. Car drivers registered via opt-in to make use of the HOV advantages would have their vehicle equipped with an additional retrofit eCall 112 device and have installed an app on their smartphone: in this technology environment, AVOV can be used to create incentives to carpoolers (drivers and passengers). The transmission of vehicle occupancy data would be initiated on request by TSM operations focused on monitoring situations such as entering a congestion zone, access to a highway or to preferential parking.

\subsection{HOV incentives and solo driving disincentives}

Higher vehicle occupancy can be used to create preferences such as:

- time savings via priority highway access at ramp metres (Section 3.3.1)

- time and cost savings via preferential parking and parking cash-out (Section 3.3.2) 
- $\quad$ cost savings in road- and congestion pricing (Section 3.3.3)

- cost savings in CAZ/low emission zones and congestion zones ${ }^{24}$ (Section 3.3.4).

In the following, these strategies are briefly depicted.

\subsubsection{Time savings: ramp metering and traffic control}

Ramp metering is promoted and applied at larger scale particularly in the $\mathrm{US}^{25} \mathrm{EU}$ member states and Israel (Bielefeldt et al., 2007) have investigated and applied joint projects. The German Road and Transportation Research Association (FGSV) developed 'Advice and reference notes on access and traffic control strategies' in 2008; recent pilot evaluations $^{26}$ are also positive. Further research could combine eCall 112 data and ANSC approaches (Section 2.9).

Figure 6 Ramp metering on north western to northern connection in Auckland, NZ (see online version for colours)

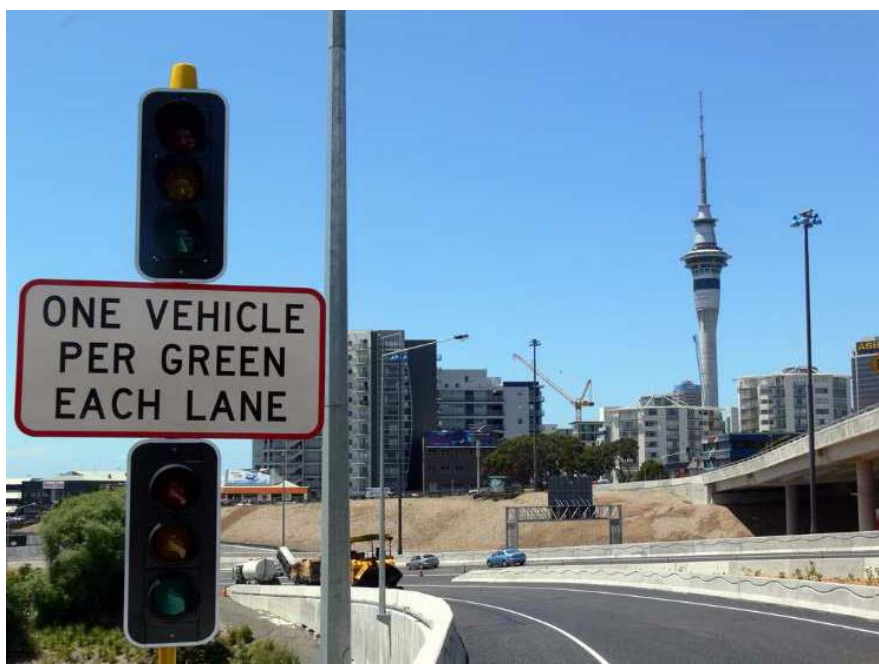

Source: Wikimedia (https://en.wikipedia.org/wiki/Ramp_meter\#/ media/File:North_Western_to_Northern_On.jpg

The US DOT promotes ramp metering in order to:

1 reduce travel times

2 reduce no. of collisions

3 reduce emissions caused by road transport.

\subsubsection{Time and cost savings via preferential parking and parking cash-out}

The EU-funded ICARO (1999) (https://trimis.ec.europa.eu/sites/default/files/project/ documents/icaro.pdf) project investigated preferential parking as carpool incentive in EU countries and Switzerland. For the USA, numerous reports (Pratsch, 1975a) reveal the strong impact of parking privileges on carpool participation since the 1970s including 
parking cash-out (Breinholt and Shoup, 1997; U.S.EPA, 2001; Shoup, 2005) as effective measure to shift commuters away from solo driving. Employers would appreciate reliable vehicle occupancy data as base for cashing-out expenses previously spent on parking subsidies.

Figure 7 HOV bypass at highway access point (see online version for colours)

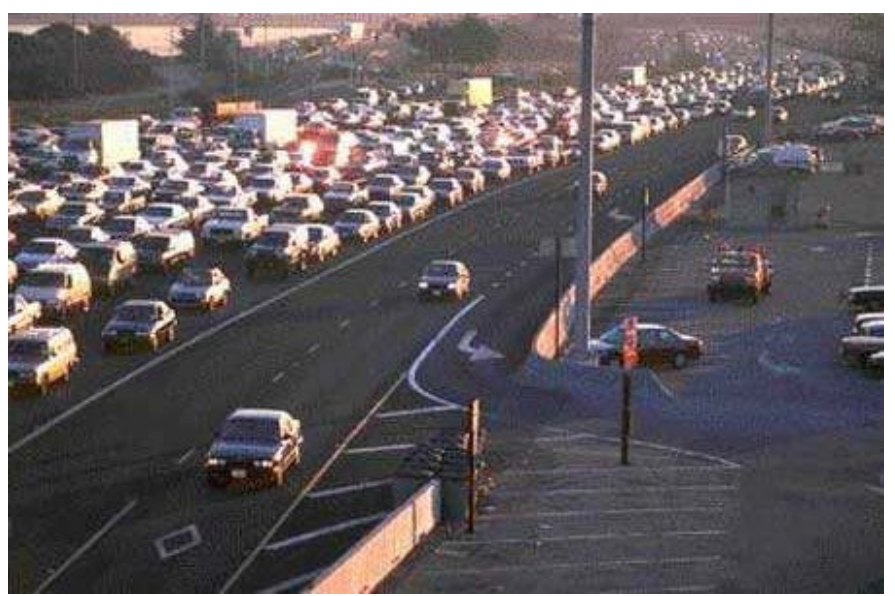

Source: http://www.hovworld.com (download 2005)

Figure 8 Preferential carpool parking in the City of Salzburg, Austria (see online version for colours)

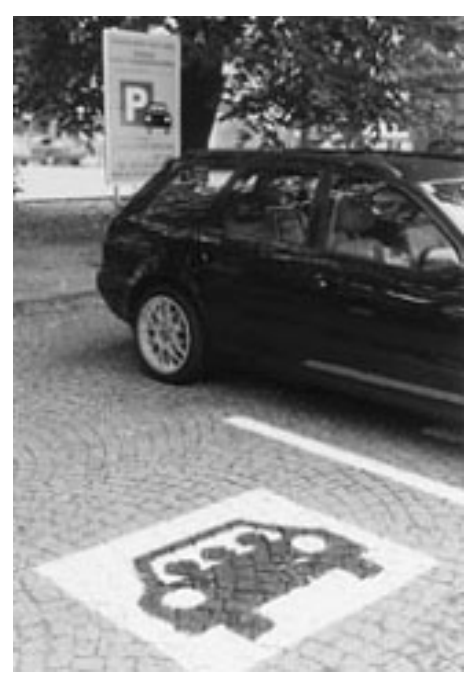

\subsubsection{Cost savings in road- and congestion-pricing}

Financial advantages in road pricing and congestion pricing may have strong impact on mode choice; Alpert illustrates significant toll savings for HOVs on their daily peak hour commutes. 
Figure 9 Highway toll rates (Alpert, 2017) and HOV 2+ discount (no toll) in the Washington, DC area (see online version for colours)

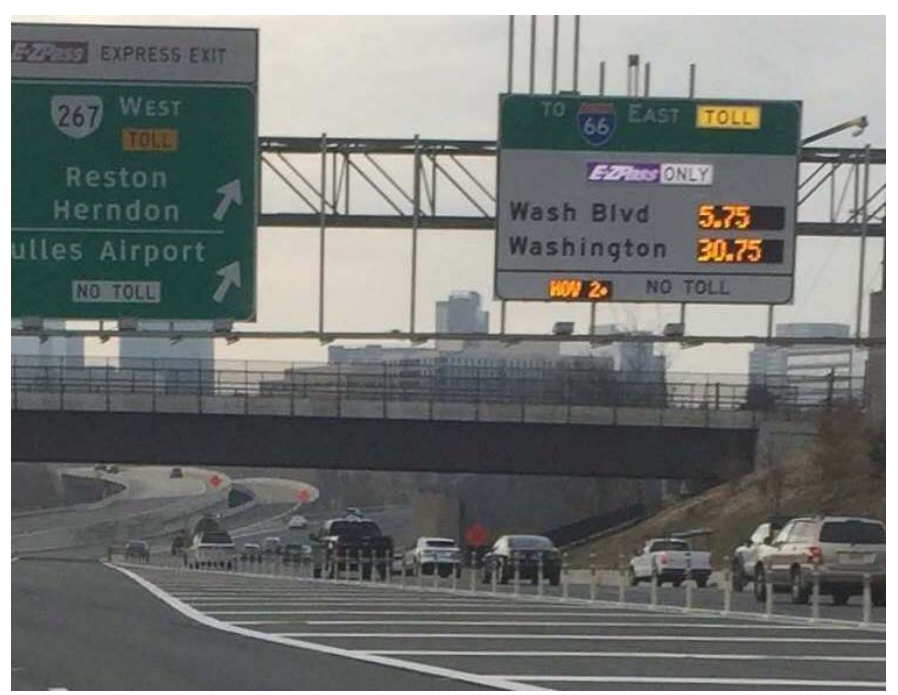

Source: Alpert (2017)

\subsubsection{Cost savings in clean air zones/low emission zones and congestion zones}

What should be treated with caution is opening extra lanes to (ultra-) low- or zero-emission vehicles irrespective of their occupancy. As implemented most recently in Nottingham, UK, ultra-low emission vehicles (ULEVs) using bus lanes can now be identified automatically: in 2004, Poole questioned if hybrids were right for California's HOV lanes anticipating foreseeable congestion levels undermining the concept of HOV lanes.

However, with an effective enforcement technology, bus lanes and HOV lanes might keep road safety standards and their performance, also for bus and bicycle users.

\subsection{Open questions}

There are several open questions with regard to the concept:

- Further development of eCall 112 legislation is unknown, including the question of whether the European legislative framework can be amended to require mandatory modifications to the MSD in order to include the 'number of passengers' in eCall 112 data?

- How can TSM authorities and air quality authorities at any level be involved while these institutions generally are not responsible for emergency call tasks?

- Details including costs for technical equipment to allow for on-site applications such as 'eCall 112-data readers' are unknown; this also comprises the applicability of VIN data for vehicle emission classification and identification of additionally required onboard devices. 
- What should a detailed system layout and budget for urban and long-distance TSM operations and air quality monitoring systems look like?

- The implementation of an integrated system as described here would require supportive action at virtually all authoritative levels - can this type of enforcement approach prove to be politically assertive?

Figure 10 Access to low emission zone, London, UK (see online version for colours)

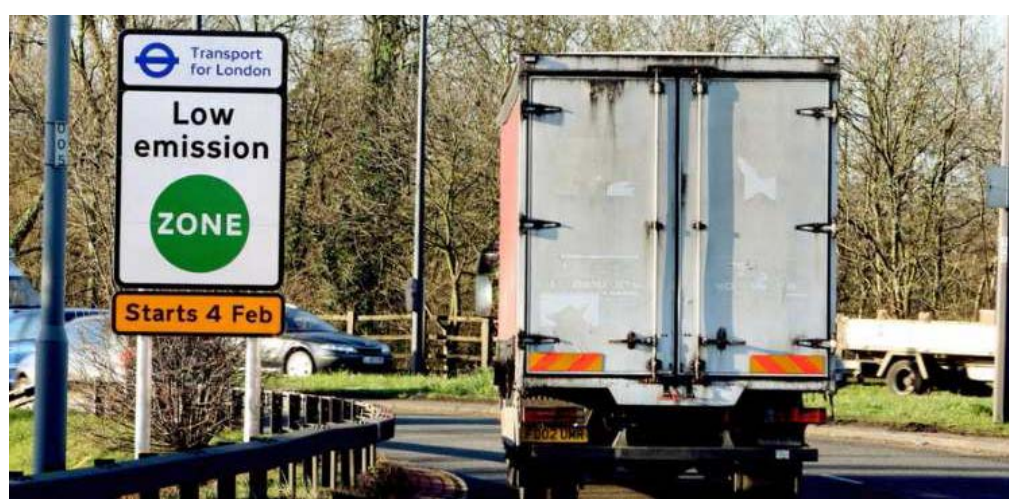

Source: http://www.verkehrsrundschau.de

Figure 11 Nottingham, UK: bus and ULEV lane (ultra low emission vehicles) (see online version for colours)

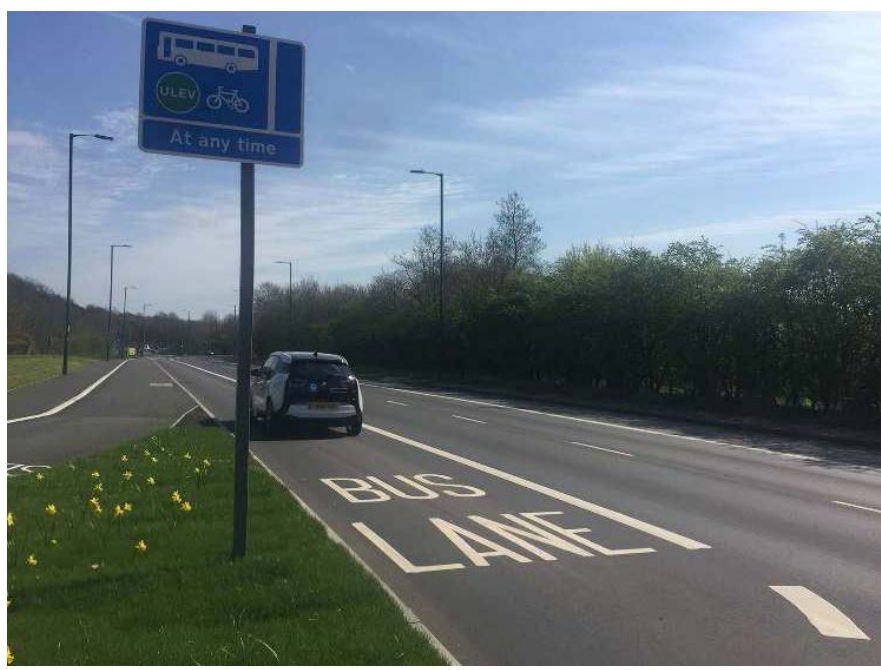

Source: Siemens (Cf. https://www.transportnottingham.com/driving/ultralowemission-vehicles/ and https://news.siemens.co.uk/news/ siemensdeploys-1-000th-traffic-enforcement-camera) 2 October 2018 


\section{Findings and recommendations}

Innovative ICT systems may substantially contribute to solving problems associated with threshold legislation in air quality and transport policy and help reduce transport sector's high volumes of GHG emissions. Irrespective of the existence of HOV lanes, innovative enforcement options would be highly beneficial for TSM operations.

There is no independently evaluated TRL 9 system available for AVOV yet. However, there is a large potential in making use of eCall 112 in TSM operations. The Pan-European eCall deployment allows for near-term development of innovative enforcement strategies and alternative instruments in road transport based on vehicle occupancy. Improved enforcement and resulting higher violation detection rates will not only raise public acceptance of HOV privileges, but also road users' compliance.

Answers to the open questions described here and the development of advanced tolling systems taking account of emissions and vehicle occupancy might be explored in research programmes ${ }^{27}$ provided by the EU such as Horizon 2020 and joint research activities with authorities and the scientific community in the USA. The data on "number of passengers' including the driver should become a mandatory part of the MSD transmission within eCall 112 at least due to road transport safety objectives. Further, EU authorities should investigate added value services and their large economic potential, especially for GALILEO- and EGNOS-based technologies. The chance to integrate progress of road transport safety provided by the eCall 112 into TSM operations should be considered thoroughly.

\section{Acknowledgements}

For his invaluable advice, first and foremost my thanks go to Mr. Paul Minett, founder and co-director, Trip Convergence Ltd., Auckland, New Zealand, founder and former Chair of the Ridesharing Institute; I deeply thank Mr. Lew W. Pratsch, former President, Transportation Total, Inc., and former director of national carpool and vanpool programs at the U.S.DOT and the U.S.DOE, Washington, DC; and I would like to thank Mr. Nigel Hallam, Parking \& WPL Service Manager, Nottingham City Council, for his advice on the WPL in Nottingham, UK.

Further, I would like to thank Dr Giuseppe Giulio Calabrese, Dr Alexandros Nikitas, Dr Nikolas Thomopoulos, and Dr Michael Wynn-Williams, for their advice and support; also my thanks go to the anonymous reviewers for numerous helpful comments.

Last but not least I thank Prof Dr Kai Nagel, Chair, Transport Systems Planning and Transport Telematics Department, TU Berlin, Germany, for continuous scientific advice.

\section{Disclaimer}

Data and statements presented in this article are the sole responsibility of the author and do not necessarily reflect the views of the German Environment Agency (Umweltbundesamt). 


\section{References}

Albesa, J. and Gasulla, M. (2015) 'Occupancy and belt detection in removable vehicle seats via inductive power transmission', IEEE Transactions on Vehicular Technology, August, Vol. 64, No. 8, pp.3392-3401, http://doi.org/10.1109/TVT.2014.2356443.

Alpert, D. (2017) The New $\$ 40$ I-66 Tolls Offer Great Insight into Commuter Psychology [online] https://ggwash.org/view/65796/the-new-i-66-tolls-offer-great-insight-into-commuterpsychology (accessed 19 January 2019).

Anderson, M. (2017) 'How to beat the traffic. Recent policy changes in Jakarta provide a test of the effectiveness of traffic restrictions', Science, Vol. 357, No. 6346, pp.36-37, https://doi.org/10.1126/science.aan8177.

Artan, Y., Bulan, O., Loce, R.P. and Paul, P. (2016) 'Passenger compartment violation detection in HOV/HOT lanes', IEEE Transactions on Intelligent Transportation Systems, Vol. 17, No. 2, pp.395-405.

Artan, Y., Paul, P., Perronnin, F. and Burry, A. (2014) 'Comparison of face detection and image classification for detecting front seat passengers in vehicles', IEEE Winter Conference on Applications of Computer Vision, Steamboat Springs, CO, USA IEEE2, 24-26 March, pp.1006-101.

Ballantyne, T. (2006) Automated Vehicle Occupancy Detection, ITS, 19pp.

Bergk, F., Knörr, W. and Lambrecht, U. (2017) 'Climate protection in transport: need for action in the wake of the Paris Climate Agreement', in Umweltbundesamt (Ed.): TEXTE, Dessau-Rosslau, Germany.

Bhuvaneswari, P.T.V., Raj, G.V.A., Balaji, R. and Kanagasabai, S. (2012) 'Adaptive traffic signal flow control using wireless sensor networks', 2012 Fourth International Conference on Computational Intelligence and Communication Networks, IEEE, Mathura, India.

Bielefeldt, C., Condie, H., Rotem, A., Hajsalem, H., Ramananjaona, C., Middelham, F. and Ernhofer, O. (2007) EU Ramp Metering Project Deliverable 6.3 Evaluation Results, Project funded by the European Community under the 'Information Society Programme' (1998-2002).

Billheimer, J.W. (1990) HOV Lane Violation Study, Prepared for California Department of Transportation, Washington, D.C.

Bradley, T., Bradshaw, T.F., Bradshaw, T.W., Coughlin, R.M., Derby, J., Erickson, R.H., Grasso, E.T., Herzog, R., Kilpatrick, R.D., Lowe, J., Luehring, D.W., Mahony, J.A., Maroney, D., Nickinello, L.R., Shallbetter, C.J., Sherwood, D.J., Somerville, R., Stokey, S. and Williams, J. (1980) Ridesharing: Meeting the Challenges of the '80s, The Report of the National Task Force on Ridesharing. National Task Force on Ridesharing.

Breinholt, M.J. and Shoup, D. (1997) 'Employer-paid parking: a nationwide survey of employers' parking subsidy policies', in Greene, D., Jones, D. and Delucchi, M.A. (Eds.): The Full Social Costs and Benefits of Transportation, Springer-Verlag, Heidelberg:.

Cames, M. and Helmers, E. (2013) 'Critical evaluation of the European diesel car boom - global comparison, environmental effects and various national strategies', Environmental Sciences Europe, Vol. 25, No. 15, 22pp.

Carroll, J., Seidl, M. and Cuerden, R. (2015) 'eCall phase 2: technical requirements and test procedures for the type-approval of eCall in-vehicle systems', European Commission.

Chan, C-Y., Bu, F., Singa, K. and Wang, H. (2011) Implementation and Evaluation of Automated Vehicle Occupancy Verification, California PATH Program, Institute of Transportation Studies, University of California, Berkeley.

Chan, N.D. and Shaheen, S.A. (2011) 'Ridesharing in North America: past, present, and future', in TRB (Ed.): 2011 Transportation Research Board Annual Meeting, Transportation Research Board, 20pp.

Clabburn, A. and Lane, K. (2009) 'Using existing European road capacity efficiently', in Aet, A.F.E.T. (Ed.): European Transport Conference, 15pp. 
Dale, S., Frost, M., Ison, S., Quddus, M. and Warren, P. (2017) 'Evaluating the impact of a workplace parking levy on local traffic congestion: the case of Nottingham UK', Transport Policy, October, Vol. 59, pp.153-164, 12pp, http://dx.doi.org/10.1016/j.tranpol.2017.07.015.

Decorla-Souza, P. (2008) 'Managing limited access highways for high performance: costs, benefits, and revenues', Journal of Public Transportation, Vol. 11, No. 1, pp.17-41.

Decorla-Souza, P. and Kane, A.R. (1992) 'Peak period tolls: precepts and prospects', Transportation, December, Vol. 19, No. 4, pp.293-311.

Decorla-Souza, P., Berman, W. and Halkias, J. (2011) 'Thinking outside the box to expand metropolitan travel choices', Transportation Research Record: Journal of the Transportation Research Board, Vol. 2217, No. 1, pp.111-118, https://doi.org/10.3141/2217-14.

EP and EU-Council (2015) Official Journal of the European Union, L 123, 19 May, Vol. 58, pp.77-89 [online] https://eur-lex.europa.eu/legal-content/EN/TXT/PDF/?uri=CELEX: 32015R0758\&from $=\mathrm{EN}$.

EP and EU-Council (2014) Official Journal of the European Union, L 164, pp.L164/6-L164/9 [online] http://eur-lex.europa.eu/legal-content/EN/TXT/?qid=1521646151691\&uri=CELEX: $32014 \mathrm{D} 0585$.

EU-Commission (2013) Official Journal of the European Union, 3 April, L 91, Vol. 56, pp.1-16 [online] https://eur-lex.europa.eu/legal-content/EN/TXT/?uri=OJ:L:2013:091:TOC.

EU-Commission (2017) Official Journal of the European Union, 17 January, Vol. 60, L 12/1-L12/96 [online] https://eur-lex.europa.eu/legal-content/EN/TXT/?uri=OJ:L:2017:012: TOC.

FGSV (2008) 'Hinweise für Zuflussregelungsanlagen (H ZRA) W 1 Ausgabe 2008', FGSV, Cologne, ISBN: 978-3-939715-75-7, 20pp [online] http://www.fgsv-verlag.de.

Goodin, G., Burris, M., Geiselbrecht, T. and Wood, N. (2013) Application of a PerformanceManagement Framework for Priced Lanes, Report No. FHWA/TX-13/5-6396-01-1, November, 46pp, Texas A\&M Transportation Institute, College Station, Texas; Sponsored by Texas DOT, Austin, Texas, USA [online] http://tti.tamu.edu/documents/5-6396-01-1.pdf.

Goodin, V., Wikander, J., Lowery, J., Ungemah, D., Stephens, D. and Poe, C. (2007) Automated Vehicle Occupancy Verification Technologies, Texas Transportation Institute, The Texas A \& M University System, College Station, Tx, USA

Hallam, N. (2015) Workplace Parking Levy Employer Handbook, Nottingham City Council, Nottingham, UK.

Hanna, R., Kreindler, G. and Olken, B.A. (2017) 'Citywide effects of high-occupancy vehicle restrictions: evidence from 'three-in-one' in Jakarta', Science, Vol. 357, No. 6346, pp.89-93, http://doi.org/10.1126/science.aan2747.

Hartwig, S. and Buchmann, M. (2007) Empty Seats Traveling: Next Generation Ridesharing and Its Potential to Mitigate Traffic and Emission Problems in the 21st Century, Nokia Research Center Bochum, Bochum.

Heinze, G.W., Herbst, D. and Schühle, U. (1982) Verkehr im Ländlichen Raum, Hannover, Akademie für Raumforschung und Landesplanung (ARL).

ICARO (1999) 'ICARO increase of CAR occupancy through innovative measures and technical instruments', in EU-COMMISSION (Ed.): European Commission (Project Funding), Vienna, Austria.

IEA (2005) Saving Oil in a Hurry, International Energy Agency, Paris.

Iparraguirre, O. and Brazalez, A. (2016) 'Communication technologies for vehicles: eCall', in Mendizabal, J., Berbineau, M., Vinel, A., Pfletschinger, S., Bonneville, H., Pirovano, A., Plass, S., Scopigno, R. and Aniss, H. (Eds.): Communication Technologies for Vehicles, Proceedings 10th International Workshop Nets4Cars/Nets4Trains/Nets4Aircraft, Springer Link ed., Springer, San Sebastián, Spain, 6-7 June.

IPCC, I.P.O.C.C. (2015) Climate Change 2014 Synthesis Report Fifth Assessment Report, IPCC. 
Joseph, S. (2016) Why Other Cities should Copy Nottingham's Revolutionary Parking Levy, CityMetric.

Kaiser, M. (2017) The Enforcement-Structure of the New GDPR - National DPAs Facing Autonomy, Hierarchy and Cooperation, Privacy in Germany PinG, 05.17, pp.192-196.

Kalikova, J., Krcal, J. and Koukol, M. (2015) 'Detection of persons in a vehicle using IR cameras and RFID technologies', Smart Cities Symposium Prague (SCSP), IEEE, Prague, Czech Republic, 24-25 June.

Kaufman, D., Hunter, N. and Taussig-Rubbo, M. (2002) Legal Authority of New York City to Impose Carpool Rule and Tolls on East River Bridges, Debevoise and Plimpton, N.Y.C, New York City, NY, USA.

Kelley, K.L. (2007) 'Casual carpooling enhanced', Journal of Public Transportation, Vol. 10, No. 4, pp.119-130.

Kisic, M.G., Blaz, N.V., Babkovic, K.B., Zivanov, L.D. and Damnjanovic, M.S. (2017) 'Detection of seat occupancy using a wireless inductive sensor', IEEE Transactions on Magnetics, April, Vol. 53, No. 4, pp.1-4, http://doi.org/10.1109/TMAG.2016.2632862.

Klebaner, S. (2018) 'Isolated car manufacturers? The political positions of the automotive industry on the real driving emissions regulation', International Journal of Automotive Technology and Management, Vol. 18, No. 2, pp.119-141, http://www.inderscience.com/info/inarticle.php? artid $=92185$.

Knopf, B., Fuss, S., Hansen, G., Creutzig, F., Minx, J. and Edenhofer, O. (2017) 'From targets to action: rolling up our sleeves after Paris', Global Challenges, 27 February, Vol. 1, No. 2, 4pp, https://doi.org/10.1002/gch2.201600007.

Komanoff (2001) 'Giuliani puts brakes on car culture', Oct 2001 op-ed in Newsday, 1 October [online] http://www.komanoff.net/cars_II/giuliani_brakes.php.

Kutter, E. (2000) Verkehrsplanerische Eckwerte einer regionalen Verkehrsstrategie, Studie zur 'Bündelungsfähigkeit' des regionalen Individualverkehrs, Frankfurt/Main, Verband der Deutschen Automobilindustrie (VDA).

Li, N. and Zhao, G. (2016) 'Adaptive signal control for urban traffic network gridlock', 2016 UKACC 11th International Conference on Control (CONTROL), IEEE, Belfast, UK.

Maclennan, R. (1995) 'HOV as a system-wide solution', in Turnbull, K.F. and Hubbard, S.M. (Eds.): HOV Systems in A New Light, 7th National Conference on High-Occupancy Vehicle Systems.

Margreiter, M., Krause, S., Twaddle, H. and Lüßmann, J. (2014) 'Evaluation of environmental impacts of adaptive network signal controls based on real vehicle trajectories', Transportation Research Procedia, Vol. 4, No. 2014, pp.421-430, https://doi.org/10.1016/j.trpro.2014. 11.032.

Mccoy, K., Andrew, J. and Lyons, W. (2016) Ridesharing, Technology, and TDM in University Campus Settings: Lessons for State, Regional, and Local Agencies, Report No. FHWA-HEP16-060, Final Report May, Volpe National Transportation Systems Center, Cambridge MA, USA; Sponsored by FHWA, Washington, DC [online] https://rosap.ntl.bts.gov/view/dot/ 12297.

Minett, P. (2011) Address to the inaugural meeting of the Ridesharing Institute, 21 January, EMBARQ Offices, Washington DC.

Minett (2014) 'People have the power', Thinking Highways North America, 1 September, 2pp [online] https://www.h3bconnected.com/people-have-the-power/.

Minett, P. (2015a) 'Invest in changing travel habits in Auckland instead of roads', Stuff, Last updated 02/07/2015.

Minett, P. (2015b) Would you be a Carpool Passenger for \$14 per day? linked.in, 3 July [online] https://www.linkedin.com/pulse/would-you-carpool-passenger-14-per-day-paulminett?trk=pulse spock-articles. 
Minett, P. (2016) 'Improving the deal to reduce the traffic', Move Forward, 18 February [online] http://www.move-forward.com/could-improving-the-deal-for-choice-passengers-reduce-thetraffic/.

Minett, P. and Pearce, J. (2011) 'Estimating the energy consumption impact of casual carpooling', Energies, Vol. 4, No. 1, 14 January, http://dx.doi.org/10.3390/en4010126.

Missiroli, M., Pierazzi, F. and Colajanni, M. (2014) 'Security and privacy of location-based services for in-vehicle device systems', International Conference on High Performance Computing \& Simulation (HPCS), IEEE, Bologna, Italy, 21-25 July.

Morris, D., Madzudzo, G. and Garcia-Perez, A. (2018) 'Cybersecurity and the auto industry: the growing challenges presented by connected cars', International Journal of Automotive Technology and Management, Vol. 18, No. 2, pp.105-118.

Morris, T., Morellas, V., Canelon-Suarez, D. and Papanikolopoulos, N. (2017) Sensing for HOV/HOT Lanes Enforcement, Final Report, St. Paul, Minnesota.

Murray, G., Chase, M.E., Kim, E. and Mcbrayer, M. (2012) Ridesharing as a Complement to Transit. A Synthesis of Transit Practice, Transit Cooperative Research Program TCRP Synthesis 98, Nelson Nygaard Consulting Associates, TRB, Sponsored by the Federal Transit Administration, Washington, DC, USA.

Nigro, N. and Burbank, C.J. (2012) Ridesharing: Context, Trends, and Opportunities, Center for Climate and Energy Solutions c2es.

Noland, R.B. (2013) 'Communicating the urgency for action on climate change. Challenges and approaches', TR News, July-August, No. 287, pp.40-43 [online] http://onlinepubs.trb.org/ onlinepubs/trnews/trnews287.pdf.

Poole, R. (2004) 'Hybrids in carpool lanes: a nonstarter - several drawbacks to plan', Commentary, Reason Foundation [online] https://reason.org/commentary/hybrids-in-carpool-lanes-a-non/, (accessed 20 January 2019).

Poole, R. (2017) Express Transit Lanes for Toll Roads, Reason Foundation Policy Brief No. 146, September [online] https://reason.org/policy-brief/express-transit-lanes-for-toll-roads/.

Poole, R. and Balaker, T. (2005) Virtual Exclusive Busways: Improving Urban Transit while Relieving Congestion, Reason Foundation, Los Angeles, CA, USA.

Poole, R.J. (2011a) 'Rethinking the politics of freeway congestion pricing', Transportation Research Record: Journal of the Transportation Research Board, Vol. 2221, No. 1, pp.57-63, https://doi.org/10.3141/2221-07.

Poole, R.W.J. (2011b) Automating HOT Lanes Enforcement, The Reason Foundation, Los Angeles, California, USA.

Poole, R.J. and Swenson, C. (2012) 'Managed arterials new application of managed lanes concept', Transportation Research Record: Journal of the Transportation Research Board, Vol. 2297, No. 1, pp.66-72, https://doi.org/10.3141/2297-08.

Poole, R.W.J. (2005) Orange County's 91 Express Lanes: A Transportation and Financial Success, Despite Political Problems, Reason Foundation, Los Angeles, Cal, USA.

Poole, R.W.J. and Orski, C.K. (2003) HOT Networks: A New Plan for Congestion Relief and Better Transit, The Georgia Public Policy Foundation, RFFI.

Pratsch, L. (1975a) Carpool and Buspool Matching Guide, DOT, Federal Highway Administration, Washington, DC, US.

Pratsch, L.W. (1975b) 'Mass transit designed by the user', Transportation, Vol. 4, No. 4, pp.403-417, http://dx.doi.org/10.1007/BF00174739.

Pratsch, L.W. (1974) 'Carpools: the underutilized resource', Civil Engineering, January, pp.49-52.

Pratsch, L.W. (1986) 'Reducing commuter traffic congestion', Transportation Quarterly, Vol. 40, No. 4, pp.591-600, https://hdl.handle.net $/ 2027 / \mathrm{mdp} .39015021808582$ ?urlappend $=\% 3 \mathrm{Bseq}$ $=609$.

Reuter, U. (2013) Luftreinhaltung und ihre Auswirkungen auf den Verkehr, Straßenverkehrstechnik, 10/2013, S, pp.628-634. 
Rodier, C., Alemi, F. and Smith, D. (2016) 'Dynamic ridesharing exploration of potential for reduction in vehicle miles traveled', Transportation Research Record: Journal of the Transportation Research Board, Vol. 2542, No. 1, pp.120-126, https://doi.org/10.3141/254215.

Schaefer, M.D. (2011) 'Mobile dynamic ridematching and e-ticketing: a Carriva-based concept to integrate public transport and carpooling', in IEEE (Ed.): IEEE Forum on Integrated and Sustainable Transportation Systems, IEEE, Vienna, Austria.

Schaller, B. (2017) Unsustainable? The Growth of App-Based Ride Services and Traffic, Travel and the Future of New York City, Schaller Consulting, New York City.

Schaller, B. (2018) The New Automobility, Lyft, Uber and the Future of American Cities, Report 25 July, 37pp [online] http://www.schallerconsult.com/rideservices/automobility.htm

Schijns, S. (2004) Automated Vehicle Occupancy Monitoring Systems for HOV/HOT Facilities, McCormack Rankin Corporation; Ministry of Transportation of Ontario, Enterprise Its Research Program, Mississauga, ON, Canada.

Schiller, P.L. (1998) 'High occupancy vehicle (HOV) lanes: highway expansions in search of meaning', World Transport Policy \& Practice, Vol. 4, No. 2, pp.32-38.

Schrank, D., Eisele, B. and Lomax, T. (2012) TTI's 2012 Urban Mobility Report Powered by INRIX Traffic Data, Texas A\&M Transportation Institute, The Texas A\&M University System, December [online] https://mobility.tamu.edu/ums/archive/\#umr2012 (accessed 20 January 2019).

Sears, P.M. (1979) Vanpooling: The Three Major Approaches, Report prepared for US Department of Energy, August [online] https://doi.org/10.2172/5764867.

Shaheen, S., Chan, N. and Rayle, L. (2017) 'Ridesourcing's impact and role in urban transportation', Access, Spring, Vol. 51, 9pp [online] http://www.accessmagazine.org/spring2017/ridesourcings-impact-and-role-in-urban-transportation/.

Shewmake, S. (2012) 'Can carpooling clear the road and clean the air? Evidence from the literature on the impact of HOV lanes on VMT and air pollution', Journal of Planning Literature, Vol. 27, No. 4, pp.363-374, https://doi.org/10.1177/0885412212451028.

Shoup, D. (2005) Parking CashOut, American Planning Association, Planning Advisory Service, Report Number 532, March, 104pp [online] http://shoup.bol.ucla.edu/ParkingCashOut.pdf.

Spiekermann, K. and Wegener, M. (1992) Bündelungspotential von Pendlerfahrten, Abschlußbericht, Berichte aus dem Institut für Raumplanung,:Institut für Raumplanung der Universität Dortmund (IRPUD), Dortmund.

Stevens, A. and Hopkin, J. (2010) UK eCall Impact Assessment, Transport Research Laboratory, Published Project Report PPR 470, 54pp, 3 August, ISBN 978-1-84608-874-2 [online] https://trl.co.uk/reports/PPR470.

STRASSENNRW (2018) Telematik im Strassenverkehr: Zuflussregelungsanlagen, Gelsenkirchen [online] http://www.strassen.nrw.de/de/verkehr/verkehrstelematik.html (accessed 21 January 2019).

Stuttgart (2018) Together for Cleaner Air: Stuttgart is Tackling It!, City of Stuttgart.

Thomopoulos, N. and Harrison, G. (2016) 'An ethical assessment of low carbon vehicles using cost benefit analysis', International Journal of Automotive Technology and Management, Vol. 16, No. 3, pp.227-247.

Towery, N.D., Machek, E. and Thomas, A. (2017) Technology Readiness Level Guidebook, Report No. FHWA-HRT-17-047. Performed By U.S.DOT Volpe Center, Cambridge MA, USA. Sponsored by FHWA Exploratory Advanced Research Program, Georgetown Pike, VA, USA. 52pp, September [online] https://rosap.ntl.bts.gov/view/dot/34280.

Transportationalternatives (2002) 'Anti-carpool study by garage owners is 'false and misleading", Transportation Alternatives Magazine, TSTC 2001, NYC Cracks Gridlock With Solo Driving Ban. Mobilizing The Region (MTR). 
TSTC (2002) Metropolitan Transportation since September 11: A Media Sourcebook, Tri-State-Transportation-Campaign (TSTC), New York [online] http://www.tstc.org/reports/911 sourcebook.pdf (accessed 21 January 2019).

Turnbull, K.F. (2002) 'Effects of changing HOV lane occupancy requirements: El Monte Busway case study', Sponsored by the U.S.DOT Federal Highway Administration, Washington, DC, USA, Performed by Texas Transportation Institute, College Station, Texas.

Turner, S. (1998) Video Enforcement for HOV Lanes: Field Test Results for the I-30 HOV Lane in Dallas, College Station, Tex., Springfield, Va., Texas Transportation Institute.

Tyrer, J.R. and Andrew, A. (2005) 'Automatic occupancy based tolling for the Forth Road Bridge', in IBTTA (Ed: IBTTA Spring Technology Workshop, 11-14 June, 26pp, IBTTA, Edinburgh, Scotland, UK.

U.S.EPA (1974) Study and Evaluation of Computer Carpool Programs in certain Metropolitan Areas, Research Triangle Park, North Carolina 27711.

U.S.EPA (2001) Parking Cash Out: Implementing Commuter Benefits Under the Commuter Choice Initiative Leadership, U.S.EPA.

U.S.EPA (2008) Sample Calculation of Emission Reductions and Fuel Savings from a Carpool Program, Emission Facts, United States Environmental Protection Agency.

U.S.EPA (2011) Transportation Control Measures. An Information Document for Developing and Implementing Emissions Reductions Programs, U.S. Environmental Protection Agency Local Government Climate and Energy Strategy Series.

UBA and BMU (2017) Diesel Cars: Software Updates are not enough for Clean Air Hendricks and Krautzberger: Grant the Switchover Premium to Clean Vehicles Only, Joint Press Release with the Federal Ministry for the Environment Umweltbundesamt.

Ungemah, D., Lowery, J., Wikander, J. and Goodin, G. (2008) 'Automated vehicle occupancy verification systems: policy and legal implications', Transportation Research Record: Journal of the Transportation Research Board, Vol. 2065, No. 1, pp.41-46, https://doi.org/10.3141/ 2065-06.

United Nations Framework Convention on Climate Change (UNFCCC) (2015) The Paris Agreement, COP 21, Paris, France.

US DOT (2010) Transportation's Role in Reducing US Greenhouse Gas Emissions, Report to Congress, Vol. 1; Synthesis Report, Vol.2; Technical Report, U.S.DOT, Washington, DC.

Walker, R., Stevens, A., Anjum, O., Suriarachchi, M. and Mcnamara, K. (2010) 'Benefits of automatic crash notification for traffic management', Road Transport Information and Control Conference and the ITS United Kingdom Members' Conference (RTIC 2010), Better Transport Through Technology, IET, London, UK.

Walton, H., Dajnak, D., Beevers, S., Williams, M., Watkiss, P. and Hunt, A. (2015) Understanding the Health Impacts of Air Pollution in London, Prepared for Transport for London and the Greater London Authority, Prepared by King's College, London.

Wikimedia (2017) [online] https://upload.wikimedia.org/wikipedia/commons/e/e9/Interstate_5 northbound_near_Shoreline\%2C_WA_-_HOV_and_VMS.jpg.

Wisman, T.H.A. (2016) 'eCall and the quest for effective protection of the right to privacy', European Data Protection Law Review EDPL, Vol. 2, No. 1, pp.59-69.

Wojtowicz, M. and Cebulla, M. (2017) 'Anonymisierung nach der DSGVO', Privacy in Germany Pin G, 17 May, pp.186-192 [online] https://www.pingdigital.de/PinG.05.2017.186.

Wood, N. and Jones-Meyer, S.N. (2016) 'Integrating automated toll discounts into a real-time ridesharing program', Transportation Research Record: Journal of the Transportation Research Board, Vol. 2597, No. 1, pp.20-27, https://doi.org/10.3141/2597-03.

Wood, N., Burris, M., Geiselbrecht, T.S., Bettger, N. and Lamers, D. (2017) 'Application of traffic thermostat for I-30 managed lanes in Dallas, Texas', Transportation Research Record: Journal of the Transportation Research Board, Vol. 2616, No. 1, pp.104-113, https://doi.org/10.3141/2616-11. 
Wshah, S., Xu, B., Bulan, O., Kumar, J. and Paul, P. (2016) 'Deep learning architectures for domain adaptation in HOV/HOT lane enforcement', 2016 IEEE Winter Conference on Applications of Computer Vision (WACV), IEEE, Lake Placid, NY, USA, 7-10 March.

Xu, B., Paul, P., Artan, Y. and Perronnin, F. (2014) 'A machine learning approach to vehicle occupancy detection', IEEE 17th International Conference on Intelligent Transportation Systems (ITSC), IEEE, Qingdao, China, 8-11 October, pp.1232-1237.

Zanella, A., Bui, N., Castellani, A., Vangelista, L. and Zorzi, M. (2014) 'Internet of things for smart cities', IEEE Internet of Things Journal, Vol. 1, No. 1, pp.22-32.

\section{Notes}

1 Limits for vehicle emissions according to EURO classifications (EURO 0-EURO 6 and EURO 0-EURO VI).

2 Automated vehicles are not discussed in the article; automation refers to vehicle occupancy detection and verification only.

3 Bundesverwaltungsgericht Press Release Nr. 9/2018, 27 February 2018 [online] https://www.bverwg.de/de/pm/2018/9; Administrative court of Gelsenkirchen includes motorway A40 into traffic access regulation zone, 15 November 2018 [online] http://www.vggelsenkirchen.nrw.de/behoerde/presse/pressemitteilungen/15_181115/index.php.

4 https://www.transportnottingham.com/no-clean-air-zone-for-nottingham/.

5 Outside the USA, several HOV-lanes have been built in Canada, Australia, and New Zealand; very few only in the EU: Leeds, the UK; Madrid, Barcelona, Spain; Paris, France.

6 Automated vehicle occupancy verification refers to automated detection of occupancy in conventional vehicles; autonomous or automated vehicles are not explored here.

7 https:/law.lis.virginia.gov/vacode/title33.2/chapter5/section33.2-501/.

8 Further EU projects such as eTEN and Dedicated Road Infrastructure for Vehicle Safety in Europe (DRIVE) were focused on the deployment of telecommunication networks-based services (e-sevices) and targeted Safety in Road Transport as well as the eEurope mission of an information society for all.

9 http://www.acea.be/press-releases/article/auto-makers-equip-all-newcar-models-with-lifesaving-ecall.

10 For the eCall context see the EU-funded global navigation satellite system named after Galileo Galilei (http:/galileognss.eu/auto-makers-equip-all-new-car-and-van-modelswith-life-savingecall/).

11 European Geostationary Navigation Overlay Service [online] https:/www.gsa.europa.eu/ egnos-growing.

$12 \mathrm{http} / / /$ iheero.eu/i_heero-results-show-how-ecall-could-improve-buscoach-lorry-safety/.

13 European Standards involved comprise EN 15722:2015, EN 16062, EN 16072, EN/ISO 24978, ETSI TS 126267, and ETSI TS 124008.

14 https://www.bosch-connectivity.com/products/telematics-ecall-plug/.

15 Regulation (EU) 2015/758, p.78, No. 13.

16 For a glossary of key ridesharing terms, cf. Table 1 (Chan and Shaheen, 2011, p.5).

17 ICARO project report, Best practices part 1, April 1999, as cited in Schijns (2004, p.17).

18 For 'the first self-powered parking sensor', cf.: http://parkhere.eu/.

19 As of November 2010, Poole (2011b, p.7)

20 Regulation (EU) 2016/679 of the EP and of the Council of 27. April 2016 on the protection of the individual with regard of the processing of personal data and on the free movement of such data and repealing Directive 95/46/EC/ [online] https://eur-lex.europa.eu/eli/reg/2016/679/oj (cf. Kaiser, 2017). 
21 cf. traffic prioritisation system SiTraffic [online] https://www.siemens.com/global/en/home/ products/mobility/roadsolutions/connected-mobility-solutions/sitraffic-stream.html

22 https:/ttfl.gov.uk/info-for/media/press-releases/2018/june/deliveringthe-next-generation-ofurban-traffic-management.

23 ISO 3779 [online] https://www.iso.org/obp/ui/\#iso:std:iso:3779:ed-4:v1:en.

24 Cf. https://www.siemens.com/global/en/home/products/mobility/roadsolutions/enforcementand-tolling-solutions/low-emission-zone.html.

25 US DOT FHWA, 18 January 2018 [online] https://ops.fhwa.dot.gov/freewaymgmt/ramp metering/index.htm.

26 cf. Landesbetrieb für Strassenbau NRW 2018 STRASSENNRW 2018, Telematik im Strassenverkehr: Zuflussregelungsanlagen, Gelsenkirchen [online] http://www.strassen.nrw. de/de/verkehr/verkehrstelematik.html.

27 cf. Horizon 2020, e.g., http://ec.europa.eu/programmes/horizon2020/. 